Вашак Оксана

кандидат педагогічних наук, доцент, доцент кафедри дошкільної освіти Полтавського національного педагогічного університету імені В. Г. Короленка,

м. Полтава, Україна ORCID: 0000-0002-7091-8242, e-mail:vashak1971.oa@gmail.com

Мартиросян Людмила кандидат філологічних наук, доцент, доцент кафедри українознавства та гуманітарної підготовки Української медичної стоматологічної академії, м. Полтава, Україна ORCID: 0000-0003-0338-0240 e-mail:_ludmila_martirosyan@ukr.net

\title{
ОСОБЛИВОСТІ УКРАЇНСЬКОГО РЕГІОНАЛЬНОГО ПИСАНКАРСТВА ЯК ЗАСІБ ПОЛІКУЛЬТУРНОГО ВИХОВАННЯ СТУДЕНТСЬКОЇ МОЛОДІ
}

\begin{abstract}
Анотація. У статті досліджено особливості українського регіонального писанкарства як засобу полікультурного виховання студентської молоді; порушено проблеми педагогічного й виховного значення українських народних, національно-культурних традицій у формуванні загальнолюдських цінностей особистості; увагу акцентовано на прадавніх звичаях українського народу, серед яких - розписування писанок.

Зосереджено увагу на аналізі наукових праць, у яких переконливо доведена важливість залучення майбутніх фахівців до народної культури, історії, мистецтва на принципах регіонального підходу; на проблемі розпису українських писанок у різні часи; наголошено на особливостях українського писанкарства як декоративного мистецтва. Тому актуальність досліджуваної проблеми є очевидною і зводиться до того, що на сучасному етапі розвитку українського суспільства відкриваються широкі можливості для оновлення змістового контенту освіти i, у такий спосіб, на основі національного, народознавчого, регіонального принципів реалізуються головні завдання полікультурного виховання студентів у закладах вищої освіти.

Однак проблема ознайомлення майбутніх фахівців із регіональними особливостями українського писанкарства як засобом полікультурного виховання залишається недостатньо вивченою.
\end{abstract}

(C) Вашак O.,

Мартиросян Л., 2021 
Цікавим є ретроспективний аналіз наукових джерел як свідчення ретельної роботи щодо збирання й вивчення українських писанок ученими, етнографами, мистецтвознавцями на теренах України в цілому, й на Слобожанщині та Наддніпрянщині зокрема.

У сучасному культурно-освітньому просторі феномен писанки досліджується й популяризується, залучаючи до національних скарбниць не тільки вітчизняних студентів, а й студентів-іноземців, 3 їхньою особливою ментальністю та захопливим пізнанням України, іiі цінностей i традицій великого народу.

Ключові слова: народні традиції, українське регіональне писанкарство, орнаментальні мотиви, мистецтво розпису писанок, культурна спадщина, національне виховання, полікультурне виховання, національна свідомість, заклади вищої освіти, майбутні фахівці.

Постановка проблеми. Педагогічне й виховне значення українських народних традицій полягає в тому, що вони є результатом зусиль багатьох поколінь і важливим засобом національного виховання молоді. Серед найцікавіших і прадавніх звичаїв українського народу - розписування писанок. Залучення студентів до вивчення, виготовлення та орнаментування писанок як засобу національного виховання розвиває в них не лише творчість, а й естетичні смаки, прищеплює шанобливе ставлення до праці, народних ремесел, вчить пишатися етнонаціональними надбаннями, які формують у майбутніх фахівців почуття приналежності до свого народу, його традицій, мистецтва, історії.

Наукові праці М. Верховинця, О. Воропая, С. Килимника, О. Пчілки, С. Русової, В. Сухомлинського, М. Стельмаховича, К. Ушинського та ін. переконливо довели важливість залучення молоді до народної культури, історії та мистецтва на принципах регіонального підходу.

Аналіз останніх досліджень 3 проблеми. Проблемі регіональних особливостей розпису українських писанок у різні часи були присвячені наукові дослідження багатьох учених. Так, історичне походження писанок на Галицькій Волині вивчалося М. Кордубою (2018); особливості писанок Катеринославщини представлені у роботах Ю. Датченко (2018); проблема українського писанкарства як декоративного мистецтва $є$ у дослідженнях О. Білоус (2001), С. Танадайчук (2015), М. Сумцова (1918) та ін. Регіональні особливості розпису українських писанок кінця XIX початку XX ст. розкрито В. Ткаченком (2017).

Мета статті полягає у здійсненні цілісного аналізу наукових психолого-педагогічних та етнографічних джерел про підходи до вивчення регіональних особливостей, виготовлення та орнаментування українських писанок як засобу полікультурного виховання студентської молоді у закладах вищої освіти.

Виклад основного матеріалу дослідження. Ознайомлення майбутніх фахівців із регіональними особливостями українського писанкарства як засобом національного виховання залишається 


\section{Інноватика у вихованні. Випуск 13.Том 1. 2021.}

недостатньо вивченою проблемою, хоча широкі можливості для оновлення змістового контенту освіти, що відкриваються перед нами на сучасному етапі розвитку українського суспільства, дозволяють нам на основі національного, народознавчого, регіонального принципів реалізувати головні завдання полікультурного виховання в закладах вищої освіти.

Писанки - це важлива складова української культури та народних традицій. Ретроспективний аналіз наукових джерел засвідчив, що з давніх часів, як на теренах України, так і на Полтавщині зокрема, проводилась ретельна робота щодо вивчення та збирання українських писанок вченими, етнографами, мистецтвознавцями. Так, доцільним для нашого дослідження є наукові напрацювання зачинателя вивчення писанкарства в Україні, відомого вченого, збирача й популяризатора етнографічних колекцій С. Кульжинського з Лубенщини (1898). Збираючи писанки, автор зміг розширити та поповнити свою колекцію і це дало йому можливість у 1898 р. видати багатоілюстрований каталог з особистим аналізом писанок «Опис колекції народних писанок», що містив зразки 2219 писанок, з яких 400 були представлені у кольорі. Кожна з них мала порядковий номер, деякі навіть місце походження, рік, назву та автора. У подальшому через фахові наукові журнали було здійснено заклик надсилати до Лубенського музею авторські зразки писанок. Активну участь у цьому брали такі відомі дослідники, як К. Болсуновський (1917), В. Горленко (1882), І. Зарецький (1894) та ін. На думку науковців, це дозволило зберегти для вітчизняної етнології й мистецтвознавства значний фонд першорядних джерел, який i досі $є$ визначальним у вивченні багатьох наукових проблем з українського писанкарства.

У XIX столітті українська поміщиця і меценатка К. Скаржинська (1906) збирала писанки 3 різних регіонів України. У 1906 році вона передала власну колекцію разом із малюнками та фотографіями писанок до Полтавського краєзнавчого музею. Під час війни частина зразків згоріла. Врятувати вдалося лише 458 одиниць старожитностей. Утім, і вони яскраво свідчать про колоритність і самобутність цього мистецтва.

Продовжуючи аналізувати сучасні наукові доробки 3 українського писанкарства Полтавщини, ми не могли не торкнутися історії збірки писанок Полтавського краєзнавчого музею дослідниці полтавських писанок Г. Галян (2017). Досліджуючи історію, авторка звертає увагу на те, як під час Світової війни музеї Полтави зазнали великих збитків, зокрема й оригінали чотирьох тисяч замальовок до фундаментального альбому писанок, що були передані колишнім директором Полтавського краєзнавчого музею Костем Мощенком до США. Вони зберігаються й дотепер, але ще й досі невідомі широкому загалу поціновувачів цього народного мистецтва (Галян, 2017).

Важливою сучасною науковою працею про регіональні особливості українського писанкарства Полтавщини є робота М. Пісцової «Полтавська писанка: пізнання через інтерактиви» (2017). Автор висвітлює можливості ознайомлення 3 писанкарством за допомогою інтерактивних сучасних 


\section{Інноватика у вихованні. Випуск 13.Том 1. 2021.}

музейно-педагогічних методів і прийомів. Це досить поширений напрям у навчанні й вихованні молоді, що має на меті прищепити любов до народної творчості, доторкнутися до історичних коренів писанкарства і ще раз довести, що писанка є невичерпним джерелом пізнання матеріальної та духовної культури українців (Пісцова, 2017).

У сучасному культурно-освітньому просторі на теренах Полтави й області феномен писанки досліджується й популяризується фахівцями в етнографії, мистецтвознавстві, педагогіці, залучаючи до національних скарбниць не тільки вітчизняних студентів, а й студентів-іноземців, 3 їхньою особливою ментальністю та захопливим пізнанням України, іiі цінностей і традицій великого народу.

Аналізуючи напрацювання дослідників про українське писанкарство Київщини, зазначимо, що найстаріше зібрання писанок в Україні від кінця XIX до XXI ст. за регіональним принципом, створене М. Біляшівським (1902) братами Вадимом і Данилом Щербаківськими (1910), представлене у національному музеї українського народного декоративного мистецтва. Це один із найбільших художніх музеїв України, де зберігається унікальна колекція писанок, що має 100-літню історію. Експозиція побудована за принципами хронології та регіональності. Тут представлені як давні, так i сучасні українські писанки, що дає можливість простежити еволюцію писанки як виду народної творчості. Особливістю цієї колекції $є$ те, що вона розкриває тенденції розвитку та занепаду писанкарства в Україні. На сьогодні колекція налічує понад 4 тисячі експонатів.

У контексті вивчення проблеми про регіональні особливості українського писанкарства зупинимося більш детально на науковому вивченні писанок Слобожанщини. Відомий дослідник С. Таранушенко у праці «Мистецтво Слобожанщини XVII-XVIII ст.» (2009) представив унікальні ілюстрації різноманітних писанок (Таранушенко, 2009).

У наш час учені С. Лігостаєва (1993), Н. Пілюгіна (1993), досліджуючи писанки Харківщини (с. Валки), наголошували, що пращури, малюючи витончені узори, могли підкреслити різним орнаментуванням і фарбами їхні регіональні особливості. Цікавими науковими дослідженнями є праці В. Тітінюк (1999). Дослідниця подала назви Слобожанських писанок та їхні кольорові зображення до місцевого історичного музею як одного 3 небагатьох, що зберіг колекцію українських писанок кінця XIX - XX ст. Це дає можливість зробити певний аналіз та зіставити їх із писанками інших регіонів України (Тітінюк, 1999).

На початку XX ст. і майже упродовж усього часу радянської влади українське писанкарство як вид українського декоративно-ужиткового мистецтва було знищено практично на всій території тодішнім режимом як таке, що не відповідало комуністичній ідеології та принципам атеїзму. Оскільки українська писанка була пов'язана 3 давніми релігійними обрядами, то атеїстична влада робила все для того, аби ця традиція зникла. Тому й до сьогодні українське писанкарство, розписування традиційних писанок вважається реліктом. Етнографічних розвідок, наукових 


\section{Інноватика у вихованні. Випуск 13.Том 1. 2021.}

досліджень 3 проблеми українського писанкарства як засобу національного виховання в Україні тоді майже не відбувалося, тому дуже багато історичного матеріалу було втрачено. Розробки методичних посібників 3 писанкарства для широкого загалу 3'явилися в другій половині 90-х років ХХ ст., а саме: праця Л. Гребінщикової та О. Данілевич «Методичні вказівки до курсу «Декоративно-прикладне мистецтво. Мініатюрний живопис України. Писанки» (Гребінщикова та Данілевич, 1991).

Отже, численні зразки писанок із різних регіонів України дали змогу вченим започаткувати наукове вивчення самої писанки, а також процесів, пов'язаних 3 іiі творенням; 3'ясувати історію виникнення; розглянути специфіку традиційних воскових і невоскових технік; розкрити значення зображених символів, кольорів; описати використання писанки у звичаях та обрядах.

Християнство пов'язувало писанку з Великоднем. Писанки у древніх слов'ян були поєднані з комплексом весняних традицій. Предки слов'ян називали розписані яйця «красними яєчками». Назва «писанка» походить від слова «писати», в розумінні - прикрашати орнаментом. Український Великдень зберіг за собою назву свята «Великдень». Птахи починали нести яйця навесні, із сонцем. Тому саме яйця не тільки уособлювали собою Весну та Сонце, а й були, так би мовити, амулетом. Писанками вважалися великодні яйця, які художньо розписувалися цілющими знаками. Пофарбовані в один колір яйця називали крашанками і вони були або варені, або печені і саме їх використовували у їжу.

Дарували писанки не всім однакові: дітям давали зі світлими кольорами, молоді - 3 «сонцем», «трикветрами» та веселим зафарбуванням, господарям - здебільшого 40 «клинців», «кривульку», старцям - 3 чорним зафарбуванням. Сам процес виготовлення писанки теж мав свої особливості.

Мистецтвознавці виділяють кілька видів писанок. Вони є традиційні й нетрадиційні. Традиційні виготовляються зі справжніх курячих яєць, вони крихкі. Нетрадиційні - дерев'яні писанки-мальованки. Їх використовують винятково як сувенір. На традиційні писанки візерунки наносять різними технічними прийомами. У деяких районах була поширена техніка крапання воском зі свічки на яйце. Така писанка називається капанкою/крапанкою. В інших місцевостях побутує техніка шкрябання на фарбованих яйцях гострим предметом. Вони називаються шкрябанками, скребанками, дряпанками. Роблять також восковки-бісерки, печатанки. На думку вчених, зафарбовування в один колір характерне для всієї України. Це - крашанки. Широко використовується воскова техніка за допомогою спеціального писачка.

Орнаментика традиційних українських писанок настільки різноманітна, що дозволяє дослідникам, залежно від мети, групувати іiі за територіально-типологічними ознаками. Наприклад, вивчаючи регіональні особливості писанки, можна детально розглядати специфічні риси творів 


\section{Інноватика у вихованні. Випуск 13.Том 1. 2021.}

майстрів у локальних осередках. Регіональні відмінності проявляються в кольорових сполученнях або в домінуванні конкретних кольорів, в деталізації форм, композицій і в розподілі поверхні писанки на окремі композиційні блоки. Окрім того, регіональні відмінності, що притаманні писанці, проявляються і в поширенні знаків та символів, виключному використанню їх лише в окремих регіонах.

Сьогодні на основі локальних особливостей традиційної матеріальної й духовної культури, побуту народу визначаються етнографічні райони писанкарства (Артюх та ін., 1993). Більш узагальненим є регіональний розподіл, здійснений Т. Кара-Васильєвою (1992): писанки Наддніпрянщини, Поділля, Полісся, Волині, Прикарпаття, Карпат. Детальний аналіз регіональної специфіки орнаментальних мотивів українських писанок розкрито дослідницею В. Манько (2008) у праці «Українська народна писанка», де наочно продемонстровано локальну спорідненість і характерні риси візерунків різних регіонів, зокрема Київщини, Полтавщини, Харківщини.

У наукових дослідженнях М. Біляшівського (1902), братів Вадима i Данила Щербаківських (1910), Е. Беняшівського (1902), С. Таранушенко (2009), В. Тітінюк (1999) та ін. є чітка класифікація орнаментів українських писанок за такими групами: геометричні, рослинні, зоологічні, антропологічні та побутові. Кожне орнаментування писанок, на думку вчених, мало своє значення: «кривулька» - нитка життя, вічність сонячного руху; «безконечник» - вияв філософської думки - початок $\mathrm{i}$ кінець; «гачковий хрест» («тригвер») - ружа, зірка. Група орнаментів, яка найбільше побутує на українських писанках, показує різноманітні знаки Всесвіту і Сонця. Їх основа, на думку дослідників, - це символічне зображення Сонця, яке $\epsilon$ орнаментом світла і життя. Колесо - це символ безсмертя; Сонце - символ світла і життя; Хрест - символ Всесвіту; Тригвер - символ Пресвятої Трійці; Дерево життя- символ життєвої осі; Дубовий листок - символ дубу й т. ін.

Учені, які в різні часи вивчали розпис та орнаментування писанок, зазначали, що для їх розпису українці використовували цілу низку тільки природних барвників. Зокрема, етнографи виділяють найпоширеніші кольори: «жовтило» (варена кора з яблуні, шафрану), «чорнило» (насіння соняшника), «зеленина» (відварені житні висівки 3 додаванням насіння соняшника), «темно-коричнева» (варена кора 3 дубу, вільхи) і т. ін. Сьогодні існує досить сталий перелік вживаних по всій країні природних барвників та отриманих із них фарбувальних відварів і соків для утворення таких кольорів: брунатний - дубова кора, кора вільхи; бежевий або коричневий - гречана полова; фіолетовий - квіти фіалок; лавандовий чорний виноград; рожевий - журавлина; світло-червоний - столовий буряк, чорниця; червоний - звіробій; від помаранчевого до червонокоричневого, теракотового - цибуля; від жовтого до золотистого березове листя; жовтий - кора яблуні-дички, шкаралупа та листя волоського горіха, гречана солома; світло-жовтий - морква, шкірка 


\section{Інноватика у вихованні. Випуск 13.Том 1. 2021.}

апельсина або лимона; зелений - шкірка зелених яблук, полова конопляного насіння, паростки жита; світло-зелений, листя шпинату, кропу, кропиви; синій - червонокачанна капуста, шовковиця; чорний лушпиння соняшника, вільха.

Унікальну писанку 3 глини було виявлено під час науковоетнографічної експедиції у Полтавській області, датовану X століттям. Досліджуючи матеріали археологічних експедицій з вивчення трипільської культури V-II тис. до н. е., вчених уразили орнаментальні малюнки на кераміці, які дуже нагадували орнамент на сучасних українських писанках.

Зупинимося на регіональних особливостях українських писанок Полтавщини. Вони мали симетричний поділ (або без нього) чорного, вишневого, іноді зеленого суцільного тла, по якому вільно розкидані обкреслені білим контуром рослинні мотиви: «дубове листя», «ружі», «тюльпани» білого, жовтого чи червоного кольорів. Світлими були писанки, у яких на білому, червоному, жовтому або світло-зеленому тлі досить товстим білим контуром обкреслювали крупні рослинні чи геометричні орнаменти, розфарбовані у два-три кольори. Традиційними фарбами була червона, зелена і жовта. Писанки Полтавщини мають різноманітну символіку: рослинні мотиви - «дерево життя», у вигляді дерева 3 трьома гілочками у вазоні, квітка, дубовий листочок, пагінці; орнітоморфні мотиви - «сороки», «півники», «голуби», «баранці», «баранячі ріжки», а також різні мотиви квітів, «гусячі лапки», «рожа», «сосонка» і т. ін. (Ткаченко, 2017).

Аналіз наукових досліджень учених, етнографів, мистецтвознавців дає підстави стверджувати, що кожна писанка на Полтавщині мала свою оригінальну місцеву назву рослинного орнаменту: «хмелик», «кленовий лист», «бруньки», геометричного орнаменту: безконечник, восьмикутні зірки, скісні хрести та тваринного орнаменту: «шулині», «гусячі лапки», «качині лапки». Так, у Пирятинському повіті, в с. Каплинцях і в інших селах губернії, орнамент розміщували поперечними пасочками й писанку називали «торчова», «рожа». Такий різноманітний поділ, на думку дослідників, міг бути в кожному селі. У м. Луком’є Лубенського повіту розписували писанки триколірно: чорне тло і жовтий, зелений рослинний орнамент: шести- і восьмипелюсткові «рожі», або декілька вертикальних смуг. У Лубнах теж писали восьмикутні «рожі», але промені їх викінчували невеличкими трикутниками, традиційно писали «сорококлин», а орнамент був у вигляді скісних хрестів жовтого, зеленого, червоного кольорів, тому й називали його «сорочі стрілки». Писанки с. Гудими Лохвицького повіту оздоблювали промінним сонцем і називали «промінчики», «жоржини».

Як бачимо, унікальні регіональні особливості орнаментування писанок дають можливість доторкнутися до історії та походження кожного виробу у найменших селах України. Залучаючи студентів до ознайомлення 3 такими особливими витворами народного мистецтва, ми можемо реалізовувати завдання національного виховання. 


\section{Інноватика у вихованні. Випуск 13.Том 1. 2021.}

Зауважимо, що кольорова палітра та орнаментування писанок Київщини дуже схожа 3 писанками Полтавщини. Проте для Київщини притаманне збереження прадавніх елементів: «безконечник», «гребінець», «вітрячок» і розпис відрізняється тяжінням до м'яких червоних тонів: рожево-червоні, деколи жовті на темно-бордовому, коричневому або зеленому тлі (Ткаченко, 2017). Вони були не дуже яскраві. Теплі кольори писанки свідчили про те, що вони пов'язані із сонцем.

Зазвичай серед елементів розпису можна зустріти ніжний солярний орнамент, рослинні мотиви; дзеркальну симетрію - писанку ділили на чотири частини, де кожна з цих частин була власним віддзеркаленням; а от геометричні мотиви - рідкість.

Символ «дерево життя» також набував поширення в орнаменті писанок Київщини. Зображення були дуже реалістичними, 3 часом перейшли на абстрактні, трансформувавшись у тризуби. Найбільш розповсюджені, на думку етнографів, були стилізовані польові квіти («дзвоники», «тюльпани», «хмелики», «ружі»), безконечники або хвилясті лінії, «берегиньки», «трироги».

Як бачимо, саме таку орнаментику та кольорову гаму українських писанок використовували наші пращури і саме такі назви були у вжитку людей тих часів. Тому, аби не втрачалася першооснова творчості, ми не маємо права осучаснювати ці місцеві орнаменти, називати їх сьогоденними назвами. Адже зараз українське писанкарство є досить доступним і тому відбувається повсюдне запозичення регіональних способів декорування яєць. Це спричиняє нівелювання специфіки орнаментування писанок, що врешті-решт негативно впливає на їхню унікальність, тобто зменшує художню цінність українського писанкарства загалом.

На нашу думку, неможливо переоцінити роль українського писанкарства у полікультурному вихованні студентства, оскільки в кожному регіоні були неповторні, самобутні орнаменти, які найяскравіше відображали самобутність i особливість кожного куточка України. Залучаючи молодь до ознайомлення 3 регіональними особливостями писанкарства, ми можемо реалізовувати найголовніші завдання національного виховання, які пов'язані з вивченням українських народних традицій, звичаїв, обрядів, пов'язаних 3 культурою та декоративноужитковим мистецтвом.

Висновки і перспективи подальших розвідок. Отож, дослідження особливостей українського регіонального писанкарства як засобу полікультурного виховання студентської молоді неодмінно сприятиме розвиткові в майбутніх фахівців естетичних смаків і поваги до культурної спадщини своєї країни та усвідомленню національної ідентичності, а мистецтво виготовлення, орнаментування й розпису писанок забезпечить шанобливе ставлення до праці, народних ремесел, етнокультурних надбань, які дозволять нам доторкнутися до історичних коренів писанкарства, i, безперечно, сформують загальнолюдські цінності особистості. 


\section{Інноватика у вихованні. Випуск 13.Том 1. 2021.}

Перспективу подальших досліджень ми вбачаємо у вивченні й популяризації у закладах вищої освіти народних традицій різних етнічних груп на території України та за їі межами.

\section{СПИСОК ВИКОРИСТАНИХ ДЖЕРЕЛ}

Галян, Г. (2017). Писанка в патріаршому музеї Полтавщини. Старожитності Посулля - Autiguitis of the Sula Regions. Пам'яті С. К. Кульжинського (1867-1943) (Україна, м. Київ) (відп. ред. Супруненко О.Б., редкол.: Біляєва С. О., Ковальова І. Ф., Кулатова І. М., та ін.), К.: Центр пам'яткознавства НАН України та УТОПIК, IV кол. вкл. CС. 46-51.

Пісцова, M. (2017). «Полтавська писанка»: пізнання через інтерактиви. Старожитності Посулля - Autiguitis of the Sula Regions. Пам'яті С. К. Кульжинського (1867-1943) (Украӥна, м. Київ) (відп. ред. Супруненко О. Б., редкол.: Біляєва С. О., Ковальова I. Ф., Кулатова I. М., ma ін.), К.: Центр пам'яткознавства НАН України та УТОПІК, IV кол. вкл. CC. 127-131.

Таранушенко, С. (2009). Українські писанки, як пам’ятки народнього малярства (до постановки питання). Наукова спадщчина. Харківський період. Дослідження 1918 - 1932 рр. : монографічні видання, статті, рецензії, додатки, таранушенкознавчі студіі. (Україна, м. Харків) (упор. М. Красиков, О. Савчук; наук. ред. та автор передм. М. Красиков). Х : ATOC. CC. 219-226.

Тітінюк, В. (1999). Писанки Слобожанщини. Народне мистецттво, № 1-2. CC. $48-49$.

Гребінщикова, Л., Данілевич, О. (1991). Методичні вказівки до курсу «Декоративно-прикладне мистецтво. Мініатюрний народний живопис України. Писанки». Х.: ХДПУ.

Культура і побут населення України (1993). (Артюх Л., Горленко В., Наулко В. та ін.). К.: Либідь.

Ткаченко, В. (2017). Регіональні особливості розпису українських писанок кінця XIX початку XXI ст. Переяславський літопис (Україна, м. Переяслав-Хмельницький), (ред. колегія: Коцур В. П. (голов. ред.) та ін.). Переяслав-Хмельницький: Вип. 12, С. 63.

Ткаченко, В. (2019). Історіографічні матеріали 3 дослідження писанкарства на Полтавщині. Актуальні питання розвитку науки в краӥнах Центральної та Східної Свропи. (Рига, Латвія, 27 вересня 2019 р.). Рига : Baltija. CC. 106-108.

Щербань, А. (2017). Трансформації орнаментації писанок і кераміки у Полтавській губернії: думки кінця XIX століття. Старожитності Посулля - Autiguitis of the Sula Regions. Пам'яті C. К. Кульжинського (1867-1943) (Україна, м. Київ) (відп. ред. Супруненко О. Б., редкол.: Біляєва С. О., Ковальова I. Ф., Кулатова I. М., та ін.). К.: Центр пам'яткознавства НАН України та УТОПІК, IV кол. вкл., С. 61-65. 


\section{REFERENCES}

Halian, H. (2017). Pysanka v patriarshomu muzei Poltavshchyny. [Easter egg in the patriarchal museum of Poltava region]. Starozhytnosti Posullia Autiguitis of the Sula Regions. Pamiati S. K. Kulzhynskoho (1867-1943) (Ukraina, m. Kyiv) (vidp. red. Suprunenko O. B., redkol.: Biliaieva S. O., Kovalova I. F., Kulatova I. M., ta in.), K.: Tsentr pamiatkoznavstva NAN Ukrainy ta UTOPIK, IV kol. vkl., SS. 46-51. [in Ukrainian].

Pistsova, M. (2017). "Poltavska pysanka": piznannia cherez interaktyvy. ["Poltava Easter egg": cognition through interactives]. Starozhytnosti PosulliaAutiguitis of the Sula Regions. Pamiati S. K. Kulzhynskoho (1867-1943) (Ukraina, m. Kyiv) (vidp. red. Suprunenko O. B., redkol.: Biliaieva S. O., Kovalova I. F., Kulatova I. M., ta in.). K.: Tsentr pamiatkoznavstva NAN Ukrainy ta UTOPIK, IV kol. vkl., SS. 127-131. [in Ukrainian].

Taranushenko, S. (2009). Ukrainski pysanky, yak pamiatky narodnoho maliarstva (do postanovky pytannia). [Ukrainian pysankas as monuments of folk painting (before asking the question]. Naukova spadshchyna. Kharkivskyi period. Doslidzhennia 1918 - 1932 rr. : monohrafichni vydannia, statti, retsenzii, dodatky, taranushenkoznavchi studii. (Ukraina, m. Kharkiv) (upor. M. Krasykov, O. Savchuk; nauk. red. ta avtor peredm. M. Krasykov). Kh. : ATOS. SS. 219-226. [in Ukrainian].

Titiniuk, V. (1999). Pysanky Slobozhanshchyny. [Easter eggs of Slobozhanshchina]. Narodne mystetstvo, No 1 - 2. SS. 48-49. [in Ukrainian].

Hrebinshchykova, L., Danilevych, O. (1991). Metodychni vkazivky do kursu «Dekoratyvno-prykladne mystetstvo. Miniatiurnyi narodnyi zhyvopys Ukrainy. Pysanky". [Methodical instructions for the course quot "Decorative and applied arts. Miniature folk painting of Ukraine. Easter eggs"]. Kh.: KhDPU. [in Ukrainian].

Kultura i pobut naselennia Ukrainy . (1993). [Culture and life of the population of Ukraine]. (Artiukh L., Horlenko V., Naulko V. ta in.), K.: Lybid. [in Ukrainian].

Tkachenko, V. (2017). Rehionalni osoblyvosti rozpysu ukrainskykh pysanok kintsia XIX pochatku XXI st. [Regional features of Ukrainian Easter eggs paintingend of the XIX beginning of the XXI century]. Pereiaslavskyi litopys (Ukraina, m. Pereiaslav-Khmelnytskyi), (red. kolehiia: Kotsur V. P. (holov. red.) ta in.). Pereiaslav-Khmelnytskyi: Vyp. 12, S. 63. [in Ukrainian].

Tkachenko, V. (2019). Istoriohrafichni materialy $z$ doslidzhennia pysankarstva na Poltavshchyni. [Historiographical materials on the study of Easter painting in Poltava region]. Aktualni pytannia rozvytku nauky v krainakh Tsentralnoi ta Skhidnoi Yevropy. (Ryha, Latviia, 27 veresnia 2019 r.). Ryha : Baltija, SS. 106-108. [in Ukrainian].

Shcherban, A. (2017). Transformatsii ornamentatsii pysanok $i$ keramiky $u$ Poltavskii hubernii: dumky kintsia 19 stolittia. [Transformations of ornamentation of Easter eggs and ceramics in Poltava province: thoughts of the end of the XIX century]. Starozhytnosti Posullia - Autiguitis of the Sula Regions. Pamiati S. K. Kulzhynskoho (1867-1943) (Ukraina, m. Kyiv) (vidp. 
red. Suprunenko O. B., redkol.: Biliaieva S. O., Kovalova I. F., Kulatova I. M., ta in.), Kyiv: Tsentr pamiatkoznavstva NAN Ukrainy ta UTOPIK, IV kol. vkl., S. $61-65$. [in Ukrainian].

\title{
FEATURES OF UKRAINIAN REGIONAL EGG PAINTING AS A MEAN OF POLYCULTURAL EDUCATION OF STUDENT YOUTH
}

\author{
Oksana Vashak \\ Candidate of Pedagogical Sciences, \\ V. H. Korolenko Poltava National Pedagogical University, \\ Poltava, Ukraine \\ ORCID: 0000-0002-7091-8242, \\ e-mail:vashak1971.oa@gmail.com \\ Liudmyla Martyrosian \\ Candidate of Philological Sciences, \\ Ukrainian Medical Stomatological Academy, \\ Poltava, Ukraine \\ ORCID: 0000-0003-0338-0240 \\ e-mail:ludmila_martirosyan@ukr.net
}

\begin{abstract}
The article examines the features of Ukrainian regional Easter painting as a mean of multicultural education of student youth; the problems of pedagogical and educational significance of Ukrainian folk, national and cultural traditions in the formation of universal values of the individual are raised; emphasis is placed on the ancient customs of the Ukrainian people, including the Easter eggs painting.

The special attention is paid on the analysis of scientific works, which convincingly prove the importance of involving future professionals in folk culture, history, art on the principles of regional approach; on the problem of Ukrainian Easter eggs painting at different times; emphasis is placed on the peculiarities of Ukrainian Easter painting as a decorative art.

Therefore, the urgency of the problem is obvious and it shows that at the present stage of Ukrainian society development wide opportunities for updating the content of education opens and, thus, the main tasks of education at higher educational institutions based on national, ethnographic, regional principles are realized.

However, the problem of acquainting future specialists with the regional features of Ukrainian Easter painting as a means of national education remains insufficiently studied.

A retrospective analysis of scientific sources is important as evidence of careful work on the collection and study of Ukrainian Easter eggs by scientists, ethnographers, art critics in Ukraine in general, and in Slobozhanshchina and Nadnipryanschuna in particular.

In the modern cultural and educational space, the phenomenon of pysanka is studied and popularized, attracting to the national treasury not only domestic
\end{abstract}




\section{Інноватика у вихованні. Випуск 13.Том 1. 2021.}

but also foreign students, with their special mentality and fascinating knowledge of Ukraine, customs and traditions of the great nation.

Keywords: folk traditions, Ukrainian regional pysanka painting, ornamental motifs, art of pysanka painting, cultural heritage, national education, multicultural education, national consciousness, institutions of higher education, future specialists.

Стаття надійшла до редакиії 21.04.2021p. 